\title{
Cloud Nine: A Work of Agitprop
}

\author{
Zafer ŞAFAK \\ The Department of Western Languages and Literatures \\ The Faculty of Science and Letters \\ Iğdır University/Turkey \\ E-mail: zafersafak61@hotmail.com
}

Doi:10.7575/aiac.alls.v.5n.3p.95

Received: 07/04/2014

URL: http://dx.doi.org/10.7575/aiac.alls.v.5n.3p.95

Accepted: 14/05/2014

\begin{abstract}
Epic theater, which is formed by Bertolt Brecht in the early $20^{\text {th }}$ century and peaks in the following decades, challenges the persistent drama convention initiated first by Aristotle. Bertolt Brecht, who is propelled by Marxist convictions and dialectical conception of history while shaping his epic theatre, aims to expose social degradation, economic exploitation and political manipulation by means of epic plays. Brecht, who tries to thwart the illusion of the fourth wall through epic theatre, encourages his audience into critical and interventionist thinking so that he can warn them who have been deceived for ages under the excuse of inevitability of human fate. Acting on Brecht's innovative art and legacy, socialist feminist Caryl Churchill deals with such themes as fixed gender roles, patriarchy and power relations and she employs Brechtian epic devices in her works to deconstruct colonialist discourse and patriarchal authority after having demonstrated their connections with sexist discriminations and oppression.
\end{abstract}

The objective of this study is to introduce the main features of Brechtian epic theatre and demonstrate how Caryl Churchill deploys these epic elements in Cloud Nine to disclose power relations and instigate tolerance and social change.

\section{Keywords: Brechtian Techniques, Colonial Oppression, Social Change, Interventionist Thinking}

\section{Introduction}

According to Bertolt Brecht, art, which is a means of superstructure, has been manipulated to disguise the evils taking place in a society. Through epic theatre, Brecht has reversed the drama tradition from disguise to disclosure. What Brecht has commenced and succeeded in Germany becomes influential in different parts of the World and Britain is one of them whose social, political and economic conditions are available to welcome Brecht's epic theatre. Brecht's legacy and dramaturgy have been utilized and tailored by British playwrights for decades for the different circumstances of the Britain. Howard Brenton, David Hare, Edward Bond, Trevor Griffiths and Caryl Churchill, whose play is the main subject matter of this study, are among the influential playwrights practicing with Brecht's epic theatre. (Reinelt 1996:16).

Cloud Nine, which was written by Caryl Churchill in the second half of the $20^{\text {th }}$ century, unsettles the expectations of the readers/audience as the play follows Brechtian techniques of a performance on stage. The first act of Cloud Nine was set in $19^{\text {th }}$ century demonstrating the repressive norms of the Victorian family, which parallels the downtrodden people in the colonized countries. In the second act, which is set in the second half of the $20^{\text {th }}$ century in England, Churchill explores such topics as women's liberation, sexual revolution and gay/lesbian liberation. When the two acts are evaluated together, it can be asserted that Churchill hints colonial and sexual oppressions are similar. The play highlights and traces the extensions of long-established colonial rule of sexual and racial exploitation in modern life. Churchill aims at deconstructing gender stereotypes, undermining the ideology of colonialism, rejecting racism and sexism and asking tolerance for the "marginalized" as the human sexuality cannot be trapped into heterosexual and monogamous inclinations.

By exposing the power relations under the network of societies and particularly that of the British society, Churchill makes use of the features of Brechtian theatre especially the Verfremdungseffekt known as defamiliarization or alienation. By alienating the socio-political, cultural and economic variables through songs, role and gender reversals, which she depicts in Cloud Nine, Churchill prompts readers and audience's critical thinking and force them to think if whatever happens under the disguise of convention is inevitable or not. Caryl Churchill, who confesses that "I've soaked up quite a lot about him over the years [...] without constantly thinking of Brecht we nevertheless imagine things in a way we might not have without him" (Reinelt 1996:86). acts on the socialist feminist principles and believes that things might have happened in a quite different way if the genuine free will of the individuals is unshackled by conventional, colonial, sexual and patriarchal authorities. By employing the elements of Brechtian epic theatre in Cloud Nine, Caryl Churchill tries to derail the rigid hierarchical power relations and get rid of (post)colonial and sexual oppression. 


\section{Epic Theatre and Its Precepts}

The principles of epic theatre must precede the examination of Cloud Nine since Brechtian epic devices are heavily employed and experimented by Churchill throughout the play.

Brecht had a strong reaction to apolitical nature of theatre in which he grew up. He believed that a play must educate its audience by forcing him to view critically what is taking place in front of him. Brecht employed several techniques such as gestus, defamiliarization and historicization to intervene into the play's action and his audience so that the audience should not become emotionally involved with the play. Captions, songs, fragmented parts or episodic nature of the scenes and placing the play's plot into a distant past are all the devices employed by Brecht to assure the alienation effect. Brecht aims at reminding constantly his audience that what they are watching is artificial and presentational. Gestus is another acting technique that Brecht developed for his epic theatre. Gestus implies the physical gestures and attitudes of a character, which demonstrate his intent and personality. Other devices to achieve the alienation effect is to change the speech from first person to third person, to change the present tense to past tense and to read stage directions aloud so that the audience can hear them and remember that they are in front of a fabricated action, which gives them opportunity and time to think critically. It can be argued that epic theatre includes above-mentioned techniques to realize its objective.

"Epic theatre' is thus an umbrella term for all those technical devices and methods of interpretation - from showing the Gestus to V and H-effects - that contribute to an analytic narrative perspective. But it also embraces structural issues such as the organization of space and time so that a particular view of the individual and society is communicated." (Mumford 2009:78).

Brecht's perception of theatre is diametrically opposed to that of Aristotelian notion of theatre. While in dramatic theatre, scenes follow chronological order; in epic theatre, scenes tend to be episodic in that they are independent from each other. In realistic theatre, characters are believable which lead audience to empathize with the character. In epic theater, actors usually speak with the audience and break "the fourth wall"; actors remain outside of the character and comment on his actions. Consequently, reactions of the audience to what they see differ considerably. In this regard, it is better to reserve words to Brecht who has an ability to defend his case:

"The dramatic theatre's spectator says: Yes, I have felt like that too - Just like me - It's only natural - It'll never change - The sufferings of this man appall me, because they are inescapable - That's great art; it all seems the most obvious thing in the world - I weep when they weep, I laugh when they laugh.” (Willet 1978:71).

While this is the natural response of a traditional playgoer, those who are inclined to see a play through the lenses of criticism and subtle thought will probably utter their views in the way Brecht has expressed it:

“The epic theatre's spectator says: I'd never have thought it - That's not the way - That's extraordinary, hardly believable - It's got to stop - The sufferings of this man appall me, because they are unnecessary - That's great art: nothing obvious in it - I laugh when they weep, I weep when they laugh." (Willet 1978:71).

What derives Brecht into the modifications of the conventional theatre is the pressing need to arouse the attention of public to the socio-political facts of his time. He believed that theatre became an instrument of manipulation for public opinion thus it must be corrected.

"Brecht remained suspicious of the tendency in dramatic theatre to use these processes to channel the energy of both actors and spectators towards having similar emotions to the character... His wariness was greatly heightened by Hitler's hypnotic theatre, in which the German publics were encouraged to see the world only through the Führer's eyes." (Mumford 2009:63).

What Brecht strives to achieve is to make his audience socially critical observers for the actions presented on the stage. For instance, in Mother Courage and Her Children, when Kattrin is shot to death in her attempt to warn the town for a surprise attack, her attitude and sacrifice are juxtaposed with the behaviors of peasants who submissively wait their doom. Actors in this scene quote their lines such as 'said the woman' and audience is called upon to make a judgement on what they see. Captions also underrate the significance of traditional theatre. In scene eleven when Kattrin tries to awaken the town with the drum, audience is informed by the expression "Stone begins to speak" (Brecht 1939:751). and audience once more is called upon to make his judgement and comment by means of this instrument of distanciation. Mother Courage's agony and lullaby over her murdered daughter eventually turn out to be deeply insensitive when she says: "Hope I can pull cart all right by meself. Be all right, nowt much inside it. Go to get back in business again." (Brecht 1939:751). The statement both can be taken as a heartless pursuit of profit and an indication of alienation effect; because, Brecht possibly wants his audience to cut their emotional tie with the agony of the character and he provides no chance of purgation of feelings upon the indifferent remarks of Mother Courage. "Brecht, as we have already noted, objected to theatre that was centrally grounded in processes of catharsis, in the identificatory intensity of shared, cultic experience." (Gillet 2008:55).

Brecht implies the premise that socio-political circumstances are the determining force behind human actions. Consequently, clashes between individuals are indeed the polarizations between certain social and political phenomena. Brecht employs fragmentary or episodic structure to convey this reality to the audience:

"In order to illustrate his view that the individual operates in a world of shifting forces, she is changed by those forces and can, in her turn, respond and change them too - Brecht used a type of montage approach, juxtaposing relatively autonomous scenes, each analogous to a force field and containing its own mini-episodes. (Mumford 2009:81). 
Brecht refuses the notion of catharsis and he tries to cut the audiences' linkage with the characters portrayed on the stage. Brecht aims at uncovering conditions not representing them thus; he makes use of the process of interrupting the actions even in fragmented episodes.

"The songs, the captions, the gestural conventions differentiate the scenes. As a result, intervals occur which tend to destroy illusion. These intervals paralyze the audience's readiness for empathy. Their purpose is to enable the spectator to adopt a critical attitude (towards the represented behaviour of the play's characters and towards the way in which this behaviour is represented). (Benjamin 1998:21).

In Mother Courage and Her Children, one of the most critically acclaimed works of Brecht, alienation effect is realized through songs that are indeed irrelevant to the action portrayed on the stage. The Song of Great Capitulation in Scene 4 decomposes the unity of the theatrical illusion because the song, delivered by Mother Courage, presents a dissonance between the theme of the song and the action of the characters.

It can be argued that whatever done on Brecht's stage, particularly under the banner of epic principles, it is done for urging the audience to raise himself above the illusions of dramatic theater and make him gain awareness about the social, economic and political events taking place around his immediate environment.

"The Verfremdungseffekt (estrangement effect) is thus another method of provoking critical reflection and prompting spectators to question phenomena which they usually take for granted. As such, it is an important tool for promoting political consciousness." (Bradley 2006:7).

One point must be particularly emphasized in relation to epic theatre and alienation effect. Brecht was a committed Marxist and he felt that if Marx's social theory could be conveyed to the audience, perennial struggle between classes would be exterminated. Brecht believed that man and society must be re-analyzed in the light of how society and individual have been historically formed and how they could have been different. Thus, Brecht's theatre is not the demonstration of a fixed reality. It is a dialectical theatre.

"Brecht developed new dramatic as well as theatrical forms. Through his dramatic techniques, acting methods, and staging devices, Brecht created a dialectical theatre that would expose the contradictions in social reality" (Bradley 2006:17).

Brecht presents one of the dialectical conflicts of the play in the identity of Mother Courage. She is torn between the conflicting desires in that; to be a mother and/or a merchant. She has to reach a synthesis between these two unconciliatory wishes; yet, she is unable to do so and she sacrifices her children while she is trying to conciliate her conflicting desires.

For an overall judgement, it can be put forward that through epic theatre and its devices, Bertolt Brecht casts doubts upon the very foundations of conventional theatre, which has been treated only a form of entertainment, particularly in capitalist systems that obscures economic and socio-political realities and stimulate herd instinct. Brecht has achieved to awake and set in motion people not to follow mob mentality. Brecht has achieved his objective: to "urge" people into thought and action, as he perfectly knows people are able to think only when they have a sound reason to do so.

"Epic theatre addresses itself to interested parties 'who do not think unless they have a reason to'. Brecht is constantly aware of the masses, whose conditioned use of the faculty of thought is surely covered by this formula." (Benjamin 16: 1998).

After the elaboration of the principles of the epic theatre, it must be noted that for Caryl Churchill and other feminist intellectuals, the techniques of epic theatre offer a frame to demonstrate and "urge people to think" critically on the social practices; but, the inclusion of Brechtian epic techniques by feminists are not solely oriented towards to emphasize the socioeconomic inequalities and class conflict yet the epic techniques are also utilized to point out the sexuality, sexual discrimination and the sexual politics.

\section{Deployment of Epic Elements and Key Issues in Cloud Nine}

The use of epic elements in Cloud Nine strikes the attention of the reader/ audience at the very beginning of the play where Churchill introduces her characters in cross-gendered and cross-racial style. Characters, like Betty and Edward are successively played by a man and woman and audience recognizes the visual incongruity. By means of cross casting, the playwright inhibits the empathy and identification of audience with the characters, which is one of the prime goals of the epic theatre. Churchill proves herself much more experimental than Brecht by gender and racial reversal. Through Betty, who is played by a male actor, it is tried to be conveyed that femininity is an artificial identity constructed by patriarchal society.

Historicization is another epic feature, which is used in the play to encourage audience's critical observation. Since Churchill knows that the historicization is the enemy of conformism, she sets the first act of the play in Victorian times in Africa.

Another Brechtian element employed in Cloud Nine is the use of songs, which are profoundly reflective and interruptive. Characters' attitudes and speeches add a layer to the alienation of audience and estrangement of characters that they represent. Both Betty's expression "I am a man's creation as you see, And what men want is what I want to be" (Churchill 1989:1). and that of Joshua's "My skin is black but oh my soul is white, I hate my tribe. My master is my light" (Churchill 1989:2). reveal the fact that how Betty adopts the subordinate role of a wife in a Victorian marriage and how much Joshua internalized the values of the white colonizers even to the extent of hating his own people. 
Obviously, they are alienated from their genuine role in the society and they provide alienation effect for the audience. In the same way, Edward, who declares, "What father wants, I'd dearly like to be" (Churchill 1989:2). provides an alienation effect as he cannot follow his ideal and consent to the lot appropriated by his father.

Clive's perspective on the natives highlights how colonizers perceive the natives. "CLIVE: We are not in this country to enjoy ourselves. Must have ridden fifty miles. Spoke to three different headmen who would all gladly chop off each other's heads and wear them round their waists." (Churchill 1989:3). It is apparent that Clive, who is the mouthpiece of the white man, regards the natives uncultivated and savage people who need "domestication".

In Act one, Edward's "playing horsy" with Joshua is the ironic demonstration how white man exploits not only the territory and the wealth of native people but also how he mocks the honor and self-esteem of the native people. In the same act, it is seen that the society is male dominated and rigidly structured by the behaviour and the discourse of men. What is more interesting is the fact that women generally collaborate with men in structuring and maintaining the patriarchal status quo. "BETTY: It's Victoria's doll. What are you doing with it, Edward? EDWARD: Minding her. BETTY: You don't want papa to see you with a doll." (Churchill 1989: 8). In the same scene, it is revealed that Joshua was Christianized, which is a branch of the institutions and ideologies of the colonizers. "JOSHUA: There are many bad men sir. I pray about it. Jesus will protect us" (Churchill 1989:13). Through Joshua, who condemns his people as "bad", Churchill once again draws near to the Brechtian point of view stimulating audience to criticize the ideologies which transform people to their own benefit.

Change of verb tense from present to past is one of the features employed in the epic theatre. This quality is observed in act one between Clive and Mrs. Saunders after they had intercourse. "CLIVE: The Christmas picnic. I came. MRS. SAUNDERS: I didn't."(Churchill 1989:17). This kind of defamiliarization device is utilized to keep audience attention on the course, action rather on the end.

Monopolization of ball game by men indicates how gender roles are taught and learnt.

“EDWARD: Mama, don't play. You know you can't catch a ball. BETTY: He is perfectly right. I can't throw either.[...] EDWARD: Ellen, don't you play either. You're no good. You spoil it.[...] BETTY: Ellen come and sit with me. We'll be spectators and clap." (Churchill 1989:18).

In this scene, it is hinted that Edward leans from his father and Betty is already ready to accept her inability, thus she helps to support male superiority. Joshua's song, which closes the scene two, functions as an epic device. "JOSHUA: What can I give him, Poor as I am? If I were a shepherd, I would bring a lamb. If I were a wise man I would do my part, What can I give him, Give my heart" (Churchill 1989:28). Through the use of song, audience is reminded that Joshua presents his heart, identity to the white man. In the following scene, Joshua's flogging his people and his rejection of his origin distance himself from his tribe. "MRS. SAUNDERS: You don't mind beating your own people? JOSHUA: Not my people madam" (Churchill 1989:32). Joshua is indoctrinated with the values of white man and it is revealed that how much he is estranged when he rejects the validity of his first story about the creation. After his outright rejection of his former story, Joshua embraces a "civil" version of genesis that belongs to the colonizers. "JOSHUA: Of course it is not true. It's a bad story. Adam and Eve is true. God made man white like him and gave him the bad woman who liked the snake and gave us all this trouble." (Churchill 1989:36). Joshua not only accept the norms of the white man and defamiliarizes himself from the natives but also he looks down on women by decreasing them into the category of troublemaker, which is a landmark feature running all through the play.

Clive is horrified when he learns Harry's homosexuality and expresses his anxiety."CLIVE: The most revolting perversion, Rome fell, Harry and this sin can destroy an empire." (Churchill 1989:40). Nevertheless Harry does not have the same anxiety when he learns Ellen's relationship with his wife. "JOSHUA: The governess and your wife, sir CLIVE: What's that, Joshua? JOSHUA: She talks of love to your wife, sir I have seen them. Bad women. CLIVE: Joshua, you go too far. Get out of my sight." (Churchill 1989:43). While Harry's sexual preference is magnified and regarded as a perversion and "a disease more dangerous than diphtheria", (Churchill 1989:40). Betty and Ellen's relationship is ignored, which underlies that Betty and Ellen are reduced to unintimidating objects for the safety of the society.

In Cloud Nine, the empathy of the audience is constantly broken down by means of the devices of defamiliarization. When Joshua learns that his parents were killed by British forces, he remains indifferent and rejects going to their funerals.

"CLIVE: Joshua, do you want a day off? Do you want to go to your people? JOSHUA: Not my people, sir. CLIVE: But, you want to go to your parents' funeral. JOSHUA: No sir [...] My mother and father were bad people. You are my father and mother. (Churchill 1989:42).

Clive's fake despair and sorrow is related when he orders Joshua for a drink just after he lamented about the "accident" and proposed Joshua a day off. "CLIVE: Yes, yes of course. Good God, what a terrible thing. Bring us a drink, will you Joshua?” (Churchill 1989:42).

Marriage between Harry and Ellen stands out as another alienation effect as the audience is aware that a gay and a lesbian are made to get married. Harry states that he always longs for a happy, familial existence, which draws a stark contrast to his real situation and feelings therefore Harry's hackneyed speech alerts the audience and fulfils the "not but" strategy of epic theatre in verbal level. "HARRY: My dear friends - what can I say - the empire - the family - the 
married state to which I always aspired - your shining example of domestic bliss - my great good fortune in winning Ellen's love - happiest day of my life. (Churchill 1989:46).

Throughout the play, Joshua is portrayed amiable and docile fellow for his master but in the last scene, it becomes evident that he harbors resentment for his subordinate position. In exactly the same manner, Edward also nurses a secret hatred for his father because he does nothing to prevent Joshua when he points a gun at Clive.

In Act two, the action takes place in London in 1979; it is one-hundred years later but Churchill warns the audience in the introduction of the play it is twenty-five years later for the characters of the play. Churchill once more uses the historicization as an epic device to refer that there are some insidious continuities in the postcolonial era and it is as if only twenty-five years passed. Chronological disruptions or employment of a diachronic time perception functions as an epic device portraying the persistence of several Victorian values. Nevertheless, there are also some distinct changes in the society. In this society, it is revealed that there is no room for Clive and Joshua. Betty, Victoria and Edward begin to emancipate themselves from the dictates of a phallocentric society. Betty acquires a real job and she learns and activates the pleasures of autoeroticism, which is a kind of rebellion against her mother and husband. Victoria begins to experiment with bisexuality and this time it is Martin- Victoria's husband- who reflects the figure of Clive, struggles to come to terms with the newly blossoming feminist movement. As for Edward, he enjoys openly the freedom of being lesbian. In act two, it is informed that characters are played by actors of their own sex which reinforces that they (are) discover(ing) who really they are. Only Cathy, who is Lin's five-year-old daughter, is played by a male actor to undermine and defamiliarize the audience's prescribed expectation about the behaviour of a girl. Enactment of Edward by a female actor in act one has the same purpose with the representation of Cathy by a male actor. In act two, it is disclosed that metaphorical exploitation of womanhood and sexual repression from the former act provided a greater consciousness about sexuality leading characters to know and exercise it and thereby subverting the patriarchal system. The fact that gender roles are changeable, which have been constructed and maintained by a male dominated society, is indicated by the rebellion of women and gays who prove their potential to entertain themselves and discover new way of leading their own lives.

In act two, quarrel between Edward and Gerry seems to be a spat between married couples, which serve as alienation effect on the part of the audience who knows that they are both gays and not married."EDWARD: [...] Where were you last night? I think you owe me an explanation. We always do tell each other everything. GERRY: Is that a rule? EDWARD: It's what we agreed. GERRY: It's a habit we've got into. (Churchill 1989:58).

Victoria's husband Martin reflects how society has changed and how much Martin has adopted the feminist cause and women liberation. 'MARTIN: [...] You're the one who's experimenting with bisexuality, and I don't stop you, I think women have something to give each other (Churchill 1989:63). Victoria's husband, who allows unlimited freedom to his wife, is diametrically opposed to Betty's husband who is submerged with Victorian patriarchal values.

During the orgy in the park, Victoria and her friends challenge the men dominated society in calling out the Goddess to come and give them back the matriarchal rule that women have lost long time ago. Victoria and her friends try to reauthorize matriarchal power in challenging the society structured by men.

"VICTORIA: Goddess of many names, oldest of the old, who walked in chaos and created life, hear us calling you back through time, before Jehovah, before Christ, before men drove you out and burnt your temples, hear us, Lady, give us back what we were, give us the history we haven't had, makes us the women we can't be . (Churchill 1989:73).

Churchill employs an alienation effect in the form of doubling the roles of several characters. For instance, Edward from act one comes out and speaks with Gerry who this time replicates Harry's words. "EDWARD: Gerry I love you. GERRY: Yes, I know, I love you too EDWARD: You know what we did? I want to do it again. I think about it all the time. Don't you want to do it anymore? GERRY: Yes, of course. (Churchill 1989:77).

The playwright once again utilizes a reflective song as an alienation effect, which also includes the name of the play connotating sexual ecstasy. "ALL: Smoked some dope on the playground swings Higher and higher on true love's wings He said Be mine and you're on Cloud Nine." (Churchill 1989:77).

Cloud Nine ends up with the speech of Clive, who appears on stage for the first time in act two, and he says that he does not feel the same way as he used to feel for Betty. Clives' speech echoes his counseling about the importance of fidelity and maintaining the unity of family in act one when he discovers the relationship between Betty and Harry.

"CLIVE: You are not that sort of woman, Betty. I can't believe you are I can't feel the same about you as I did. And Africa is to be communist I suppose. I suppose. I used to proud to be British. There was a high ideal. I came out onto verandah and looked at the stars (Churchill 1989:87).

Although Churchill gives the last word to Clive insinuating that there are still effects of patriarchal rule in the postcolonial era, she reserves the last action -the gestus in Brechtian terminology- to "Bettys" from act one and act two who embrace each other.

\section{Derailing Rigid Hierarchical Relations and Getting Rid of Colonial and Sexual Oppression}

In Cloud Nine, Caryl Churchill demonstrated different types of oppressions and she portrayed how colonial and sexual oppression are intertwined. In doing so, Churchill makes use of Brechtian epic theatre techniques to stimulate audience to understand and pass a value of judgment on the ideologies, which were acknowledged universally valid. Sexual issues appear in ever part of the play and sexual revolution serve as an instrumental force to provide the change and liberation of every kind. As it is pointed out epic theatre is a dialectical presentation of events on stage, Churchill 
utilizes epic devices such as interruptive songs, monologues, cross-casting, time shift, doubling of roles in Cloud Nine to represent how social relations are generated and maintained among people. After having proved that these relations are man-made constructs, Churchill makes it clear that they are inevitably subjected to change.

\section{References}

Benjamin, Walter, (1998). Understanding Brecht, New York: Verso.

Bertolt, B. Mother Courage and Her Children, (2000). (translated by) Willet, John, The Harcourt Brace Anthology of Drama 9rd ed. W. B. Worther,

Bradley, Laura, (2006). Brecht and Political Theatre: The Mother on Stage, Oxford, Oxford University Press Churchill, Caryl (1989). Cloud Nine, London, Nick Hern Books, a division of Walker Books Limited Gillet, Robert and Sussex W.Godela, (2008). Bertolt Brecht and Legacy, Amsterdam, Rodopi B.V Mumford, Meg, (2009). Bertolt Brecht, Oxon, Routledge,

Reinelt, G., Janelle (1996). After Brecht: British Epic Theater, USA, the University of Michigan Press

Willet, John, (1978). Brecht on Theatre: The Development of An Aesthetic, New York, Hill and Wang 